\title{
Adherence to drug treatment in hypertensive patients on the Family Health Program
}

\author{
Andrea Queiróz Ungari*, Amaury Lelis Dal Fabbro \\ Department of Social Medicine, Faculty of Medicine of Ribeirão Preto, University of São Paulo
}

\begin{abstract}
The aim of the present study was to analyze adherence to drug treatment in hypertensive patients enrolled on the Family Health Program in Ribeirão Preto, São Paulo State. This transversal study was conducted between August and December 2006, in which 109 patients were interviewed using the Morisky and Green Test to measure adherence level to pharmacotherapy. Variables that may be related to adherence level were also investigated, such as demographic characteristics, health care team and health service related factors, and pharmacotherapy related factors. The test scores were analyzed by two criteria: patients were categorized as "more adherent" if they had a score from 3 to 4 (criterion 1) or a score of 4 (criterion 2); patients with other scores were categorized as less adherent. Of all patients, $79.8 \%$ and $43.1 \%$ were classified as "more adherent" according to criterion 1 and criterion 2, respectively. With regard to the possible causes of non-adherence to treatment, statistically significant $(\mathrm{p}<0.05)$ associations were identified between "trust in the doctor" or "number of antihypertensive drugs used" and the level of adherence, according to criterion 2. These results indicated adequate adherence levels to drug treatment by the patients, and highlighted the importance of professional/patient interaction, trust in the doctor and the attitude by health professionals toward users.
\end{abstract}

Uniterms: Treatment adherence. Hypertension/drug treatment. Family Health Program.

Este estudo teve como objetivo estudar a adesão ao tratamento farmacológico de pacientes hipertensos seguidos no Programa de Saúde da Família em Ribeirão Preto, SP. Realizou-se um estudo transversal entre agosto e dezembro de 2006, em que foram entrevistados 109 pacientes, utilizando-se o Teste de Morisky e Green para mensurar o grau de adesão ao tratamento. Variáveis que podem se relacionar com o grau de adesão também foram estudadas, tais como: características demográficas, fatores relacionados à equipe e ao serviço de saúde e à terapia medicamentosa. Os resultados do teste foram avaliados por dois critérios: os pacientes foram classificados como "mais aderentes" se apresentassem pontuação de 3 a 4 (critério 1) ou de 4 (critério 2); pacientes com outras pontuações foram classificados como "menos aderentes". Dos pacientes, 79,8\% e 43,1\% foram "mais aderentes" de acordo com os critérios 1 e 2 , respectivamente. Em relação às possíveis causas da não adesão, observaram-se associações significativas $(\mathrm{p}<0,05)$ entre as variáveis "confiança no médico" ou "quantidade de medicamentos anti-hipertensivos que utiliza" e "grau de adesão", pelo critério 2. Os resultados do presente trabalho indicam que os pacientes apresentam graus satisfatórios de adesão ao tratamento medicamentoso, a importância da interação profissional/paciente, a confiança no médico e a atitude dos profissionais de saúde em relação ao usuário.

Unitermos: Adesão ao tratamento. Hipertensão Arterial/tratamento farmacológico. Saúde da Família.

\section{INTRODUCTION}

Hypertension is a chronic disease and one of the major causes of morbidity and mortality in the world. It is

\footnotetext{
*Correspondence: A. Q. Ungari. Divisão de Assistência Farmacêutica, Hospital das Clínicas da Faculdade de Medicina de Ribeirão Preto, Universidade de São Paulo. Av. Bandeirantes, 3900 Monte Alegre - 14049-900 Ribeirão Preto, SP, Brasil. E-mail: andreaungari@uol.com.br
}

regarded as one of the most prevalent risk factors for coronary artery disease, cerebrovascular disease, congestive heart failure, chronic renal failure and peripheral vascular disease (Semenciw et al., 1988; Sociedade Brasileira de Hipertensão, 2006).

Although the efficacy of antihypertensive agents has been confirmed, the maintenance of blood pressure levels within the desirable range remains unsatisfactory. This is 
caused in part by non-adherence to drug therapy, which is a fundamental issue in determining treatment effectiveness (Leite, Vasconcelos, 2003; Strelec, 2000).

Adherence to long term therapy is the extent to which an individual's behavior: taking medications, following a diet and/or modifying lifestyle, corresponds with recommendations from health care providers. Estimates of the extent to which patients adhere to medication for hypertension range from $50 \%$ to $70 \%$. This variation is related to differences in study groups, duration of follow-up, methods of measurement of adherence and drug regimens used in different studies (World Health Organization, 2003).

According to the World Health Organization (2003), adherence is a multidimensional phenomenon determined by sets of factors, termed "dimensions", which involve socio-economic factors, medication therapy, patient condition, the health care provider and health care system.

The methods for assessing adherence to therapy present several limitations. The direct methods are often more accurate but are costly, require expensive equipment and hence are impractical in public health. Although the indirect methods tend to overestimate adherence and underestimate non-adherence, the interview is the most practical indirect method, since it may be applied across all levels of health care (Milstein-Moscati, Persano, Castro, 2000; Ostenberg, Blaschke, 2005)

In order to improve adherence, it is important to be aware of the patients' knowledge and preferences toward their treatment. There are numerous interventions designed to promote adherence to antihypertensive therapy. The most frequently adopted interventions are: simplification of drug regimen, patient education, motivational strategies and complex combined interventions (Katz, 1997; Schroeder, Fahey, Ebrahim, 2004). Health care providers must establish a collaborative relationship aiming to minimize adherence problems and obtain better results from the financial resources mobilized for disease control (MilsteinMoscati, Persano, Castro, 2000).

The aim of the present study was to assess the adherence to medication treatment in patients with hypertension enrolled on the Family Health Program in Ribeirão Preto, São Paulo State.

\section{METHODS}

This is a cross-sectional study designed to evaluate adherence to medication treatment as well as to identify possible factors associated with adherence in patients with hypertension referred to the Family Health Centers (NSF) I, II, III and IV, which are attached to the School Health
Center (CSE) of São Paulo University School of Medicine (FMRP-USP).

The study has been analyzed and was approved by the CSE and FMRP-USP Research Ethics Committee on June 28, 2006, according to Opinion Number 018/2006.

Power analysis was started with the number of registered subjects at NSF I, III, IV and V in 2006, giving 3203, 2991, 3233 and 2673, respectively. The number of registered hypertensive patients was then verified using the Primary Care Information System (SIAB - Sistema de Informação de Atenção Básica), with 507 (18.3\%), $541(21.2 \%), 250(10.9 \%)$ and $346(17 \%)$, respectively.

Considering a $95 \%$ confidence interval (CI) and a $10 \%$ sampling error (d), the sample size (n) of 91 patients was calculated. Overall, 109 patients $(n+20 \%)$ were included and a systematic and stratified random sample was used. In each NSF the number of registered patients $(\mathrm{N})$ was divided by the necessary sample size (n), resulting in the sampling interval. The first patients position was obtained randomly and the next by summing the sampling interval. The determination of the sample size was performed as described in Levy and Lemeshow (1991) for systematic sampling in population surveys.

Information concerning whether the patient had been included in the study, the patient name, address and telephone were obtained from patients' medical records. None of the patients were excluded.

Inclusion criteria were patients with a diagnosis of hypertension, taking antihypertensive drugs for at least 6 months prior to the study, 20 years of age or older, able to understand, verbalize and answer the questionnaire and give written informed consent to take part in the research.

Single interviews were performed at the patients' residence during the period from 16 August to 09 December 2006. Questionnaire pretesting was performed with 10 patients in order to assess respondents' understanding of the questions, intelligibility, unambiguousness and order of the questions, duration of the interview and any difficulties in using the questionnaire. No modifications to the questionnaire were made.

The questionnaire comprised general information including the number and date of the interview, a specific test to measure levels of adherence (Morisky-Green test-MGT), as well as tools to evaluate the influencing factors on adherence to pharmacotherapy: demographic characteristics and lifestyle related variables, the health care team and health care service related variables, and therapy related variables.

Hypertensive patient adherence was measured by the MGT, an easy to use questionnaire, composed of 4 objective questions, that predicts patient drug-taking behavior. 
The theory underlying this measure is that inadequate use of drugs could occur in any or all of these mechanisms: forgetting, carelessness, stopping the drug when feeling better or stopping the drug when feeling worse (Morisky, Green, Levine, 1986). The MGT scores are $0=$ Yes and $1=$ No. A total score of 0 (four "yes" answers) indicates lower adherence, and a total score of 4 (four "no" answers) indicates higher adherence to medication use.

The criterion 1 classified patients with a score from 3 to 4 as "more adherent", whereas patients with a score from 0 to 2 were classified as "less adherent". The criterion 2 classified patients with a score of 4 as "more adherent", and patients with a score from 0 to 3 as "less adherent". The adherence related variables were analyzed according to criterion 2.

Data gathered were encoded and processed using Epi Info software, version 6.0. Data were analyzed using Fisher's exact test with PROC FREQ of SAS software.

\section{RESULTS}

Table I describes the four questions of the MGT and the response rates obtained from the patients. Of all the patients, $26.6 \%$ reported having forgotten to take the antihypertensive medicine and $45.9 \%$ reported being careless at times about taking the medicines. For criterion $1,79.8 \%$ of patients were classified as "more adherent" and $20.2 \%$ as "less adherent". For criterion 2, $43.1 \%$ of patients were classified as "more adherent" and 56.9\% as "less adherent". The latter provides a more rigorous categorization, since patients are not considered adherent to the treatment unless they obtain the maximum score of 4 points.

Of the four questions used to measure adherence, the questions "When you feel better do you sometimes stop taking your medicine?" and "Sometimes if you feel worse when you take your medicine, do you stop taking it?" received higher positive ("yes") answer rates (99.1\% and $93.6 \%$ respectively), whereas "Are you careless at times about taking your medicine?" received the lowest rate $(54.1 \%)$.
Patients' demographic characteristics and lifestyle habits are described in Table II. Most of the patients were female $(84.4 \%)$, aged older than 60 years $(55.1 \%)$ (standard deviation of 11.5 years), married (56\%), white $(81.7 \%)$, and with low educational level $(65.2 \%)$.

With regard to lifestyle habits, $63.3 \%$ of patients reported having never smoked, $50.5 \%$ did not exercise, and $72.5 \%$ reported having no frequent consumption of alcohol. No statistically significant association was observed between each of these variables and the MGT's criterion 2.

As shown in Table III, $84.4 \%$ of patients reported that they always had trust in the doctors and $86.2 \%$ reported the same for health team professionals; $83.5 \%$ of patients reported that they always understood the information concerning illness and treatment given by the doctor. A significant $(p<0.05)$ association between "trust in doctor" and "adherence level" was observed.

Among patients taking 3 or more medications, $70.6 \%$ were classified as more adherent. Interestingly, $54.6 \%$ of "more adherent" patients took 7 or more pills daily, whereas $57.3 \%$ of "less adherent" patients took from 1 to 3 pills daily (Table IV). There was a significant association $(p<0.05)$ between the "number of antihypertensive medication used" and "level of adherence".

Among patients that reported having difficulty taking their pills, $81.8 \%$ were "more adherent" and $73.7 \%$ of patients whose prescription had been altered several times by the doctor were "less adherent".

\section{DISCUSSION}

The results of the present study are similar to those reported by Morisky and Levine (1986), who found that among 290 hypertensive patients studied, $67 \%$ of patients had a score from 3 to 4 (more adherent) whereas $33 \%$ had a score from 0 to 2 (less adherent). These data are also in accordance with Garcia (2003) who investigated the adherence to hypolipidemic therapy and found that $74 \%$ of patients had a score from 3-4 and 44.4\% had a score of 4 .

Silvestre-Busto et al. (2001), in a study comparing 6 indirect methods to evaluate therapy adherence, observed

TABLE I - Distribution of Responses to the Morisky-Green Test obtained from 109 hypertensive patients studied

\begin{tabular}{lcccc}
\hline Questions & \multicolumn{3}{c}{ YES } & \multicolumn{2}{c}{ NO } \\
\cline { 2 - 5 } & N & $\mathbf{\%}$ & N & \% \\
\hline 01. Do you sometimes forget to take your medicine? & 29 & 26.6 & 80 & 73.4 \\
02. Sometimes are you careless at times about taking your medicine? & 50 & 45.9 & 59 & 54.1 \\
03. When you feel better do you sometimes stop taking your medicine? & 1 & 0.9 & 108 & 99.1 \\
04. If you feel worse when you take your medicine, do you sometimes stop taking it? & 7 & 6.4 & 102 & 93.6 \\
\hline
\end{tabular}


TABLE II - Demographic characteristics and lifestyle habits distribution in hypertensive patients by level of adherence obtained from the Morisky-Green test, analyzed by criterion 2

\begin{tabular}{|c|c|c|c|c|c|c|c|}
\hline \multirow[t]{2}{*}{ Characteristics } & \multicolumn{2}{|c|}{ More adherent } & \multicolumn{2}{|c|}{ Less adherent } & \multicolumn{2}{|c|}{ Total } & \multirow[t]{2}{*}{ p Value } \\
\hline & $\mathrm{N}=47$ & $\%$ & $n=62$ & $\%$ & $\mathrm{n}=109$ & $\%$ & \\
\hline \multicolumn{8}{|l|}{ Sex } \\
\hline Male & 9 & 52.9 & 8 & 47.1 & 17 & 15.6 & $0.43^{*}$ \\
\hline Female & 38 & 41.3 & 54 & 58.7 & 92 & 84.4 & \\
\hline \multicolumn{8}{|l|}{ Age } \\
\hline$\leq 60$ years & 19 & 38.8 & 30 & 61.2 & 49 & 44.9 & $0.44 *$ \\
\hline$>60$ years & 28 & 46.7 & 32 & 53.3 & 60 & 55.1 & \\
\hline \multicolumn{8}{|l|}{ Marital status } \\
\hline Single & 2 & 33.3 & 4 & 66.7 & 6 & 5.5 & \\
\hline Married & 29 & 47.6 & 32 & 52.4 & 61 & 56 & \\
\hline Widowed & 14 & 43.8 & 18 & 56.2 & 32 & 29.3 & $0.61 *$ \\
\hline Separated/Divorced & 2 & 22.2 & 7 & 77.8 & 9 & 8.3 & \\
\hline Living together & 0 & 0 & 1 & 100 & 1 & 0.9 & \\
\hline \multicolumn{8}{|l|}{ Race } \\
\hline White & 39 & 43.8 & 50 & 56.2 & 89 & 81.7 & \\
\hline Black & 2 & 33.3 & 4 & 66.7 & 6 & 5.5 & $0.93 *$ \\
\hline Pardo & 6 & 42.9 & 8 & 57.1 & 14 & 12.8 & \\
\hline \multicolumn{8}{|l|}{ Education $* *$} \\
\hline Low & 3 & 33.3 & 6 & 66.7 & 9 & 8.3 & \\
\hline Elementary education & 31 & 43.7 & 40 & 56.3 & 71 & 65.2 & \\
\hline Middle education & 8 & 44.4 & 10 & 55.6 & 18 & 16.5 & $0.99 *$ \\
\hline High school & 3 & 42.9 & 4 & 57.1 & 7 & 6.4 & \\
\hline Higher education & 2 & 50 & 2 & 50 & 4 & 3.7 & \\
\hline \multicolumn{8}{|l|}{ Employment } \\
\hline Retired & 19 & 52.8 & 17 & 47.2 & 36 & 33 & \\
\hline Formal employment & 5 & 62.5 & 3 & 37.5 & 8 & 7.3 & $0.22 *$ \\
\hline Self-employment & 5 & 31.2 & 11 & 68.8 & 16 & 14.7 & \\
\hline Housewife & 18 & 36.7 & 31 & 63.3 & 49 & 45 & \\
\hline \multicolumn{8}{|l|}{ Smoking } \\
\hline Yes & 9 & 56.2 & 7 & 43.8 & 16 & 14.7 & $0.48 *$ \\
\hline No & 29 & 42 & 40 & 58 & 69 & 63.3 & \\
\hline Former smoker & 9 & 37.5 & 15 & 62,5 & 24 & 22 & \\
\hline \multicolumn{8}{|l|}{ Physical exercise } \\
\hline Yes & 18 & 46.2 & 21 & 53.8 & 39 & 35.7 & \\
\hline Sometimes & 7 & 46.7 & 8 & 53.3 & 15 & 13.8 & $0.83 *$ \\
\hline No & 22 & 40 & 33 & 60 & 55 & 50.5 & \\
\hline \multicolumn{8}{|l|}{ Alcohol consumption } \\
\hline No & 35 & 44.3 & 44 & 55.7 & 79 & 72.5 & \\
\hline No, I quit & 2 & 33.3 & 4 & 66.7 & 6 & 5.5 & $0.94 *$ \\
\hline Yes & 10 & 41.7 & 14 & 58.3 & 24 & 22 & \\
\hline
\end{tabular}

* Fisher's test, $* *$ complete or incomplete education 
TABLE III - Distribution of health care service/team related responses in hypertensive patients by level of adherence obtained from the Morisky-Green test, analyzed by criterion 2

\begin{tabular}{lccccccc}
\hline Responses & \multicolumn{2}{c}{ More adherent } & Less adherent & \multicolumn{2}{c}{ Total } & p-Value \\
\cline { 2 - 6 } & $\mathbf{n}=\mathbf{4 7}$ & $\mathbf{\%}$ & $\mathbf{n = 6 2}$ & $\mathbf{\%}$ & $\mathbf{n = 1 0 9}$ & $\mathbf{\%}$ & \\
\hline 01. Do you trust your doctor? & & & & & & & \\
$\quad$ Rarely & 1 & 100 & 0 & 0 & 1 & 0.9 \\
Usually & 0 & 0 & 4 & 100 & 4 & 3.7 & \\
Often & 2 & 18.2 & 9 & 81.8 & 11 & 10.1 & $0.03^{*}$ \\
Always & 43 & 46.7 & 49 & 53.3 & 92 & 84.4 & \\
I don't know & 1 & 100 & 0 & 0 & 1 & 0.9 \\
02. Do you trust the healthcare team? & & & & & & & \\
Rarely & 0 & 0 & 1 & 100 & 1 & 0.9 \\
Usually & 2 & 50 & 2 & 50 & 4 & 3.8 \\
Often & 3 & 37.5 & 5 & 62.5 & 8 & 7.3 & $0.99 *$ \\
Always & 41 & 43.6 & 53 & 56.4 & 94 & 86.2
\end{tabular}

03. Do you understand the information concerning hypertension and the treatment?

$\begin{array}{lccccccc}\text { Rarely } & 1 & 33.3 & 2 & 66.7 & 3 & 2.7 & \\ \text { Usually } & 5 & 45.5 & 6 & 54.5 & 11 & 10.1 & 0.39^{*} \\ \text { Often } & 0 & 0 & 4 & 100 & 4 & 3.7 & \\ \text { Always } & 41 & 45 & 50 & 55 & 91 & 83.5 & \end{array}$

04. Do you clarify your doubts about hypertension and the treatment?

$\begin{array}{lccccccc}\text { Never } & 3 & 60 & 2 & 40 & 5 & 4.6 & \\ \text { Rarely } & 1 & 33.3 & 2 & 66.7 & 3 & 2.8 & \\ \text { Usually } & 5 & 71.4 & 2 & 28.6 & 7 & 6.4 & 0.27^{*} \\ \text { Often } & 0 & 0 & 4 & 100 & 4 & 3.7 & \\ \text { Always } & 37 & 42 & 51 & 58 & 88 & 80.7 & \\ \text { I don't know } & 1 & 50 & 1 & 50 & 2 & 1.8 & \end{array}$

05. Do you participate in any hypertension related group?

\begin{tabular}{lccccccc} 
Yes & 4 & 44.4 & 5 & 55.6 & 9 & 8.3 & $0.99^{*}$ \\
No & 43 & 43 & 57 & 57 & 100 & 91.7 & \\
\hline
\end{tabular}

* Fisher's test

that the MGT underestimates the number of good adherents and overestimates the number of non-adherents by $7.9 \%$. Notwithstanding, the MGT remains one of the best methods for assessing adherence, and is very reliable when nonadherent patients affirm this status.

The absence of hypertension symptoms is a strong contributing factor to low adherence to treatment. However, this was not observed in the present study, since patients continued to take their medicines even in the absence of symptoms, and reported the importance of continuing their treatment when feeling bad.

Our results are in agreement with literature, since no statistically significant differences in sex, age, marital status, educational level or adherence level were found. In general, the majority of authors report that adherence level is not consistently associated with socio-demographic factors (Eisen et al., 1990).

It is noteworthy that, despite using random allocation, the majority of the interviewed patients were female $(84.4 \%)$, which raises the question whether women in general are more adherent to the health system or whether the prevalence of hypertension is higher among women in the region studied. According to Flack et al. (1996), women tend to be more adherent to antihypertensive therapy than men, achieving better blood pressure control.

There has been renewed interest in the concept of 
TABLE IV - Distribution of medication therapy related responses in hypertensive patients by level of adherence obtained from the Morisky-Green test, analyzed by criterion 2

\begin{tabular}{|c|c|c|c|c|c|c|c|}
\hline \multirow[t]{2}{*}{ Responses } & \multicolumn{2}{|c|}{ More adherent } & \multicolumn{2}{|c|}{ Less adherent } & \multicolumn{2}{|c|}{ Total } & \multirow[t]{2}{*}{ p-Value } \\
\hline & $\mathbf{N}=\mathbf{4 7}$ & $\%$ & $n=62$ & $\%$ & $n=109$ & $\%$ & \\
\hline \multicolumn{8}{|c|}{ 01. Do you have any difficulties in taking the pills? } \\
\hline Yes & 2 & 18.2 & 9 & 81.8 & 11 & 10.1 & $0.11 *$ \\
\hline No & 45 & 45.9 & 53 & 54.1 & 98 & 89.9 & \\
\hline \multicolumn{8}{|c|}{ 02. You take your pills: } \\
\hline Daily & 47 & 44.3 & 59 & 55.7 & 106 & 97.2 & $0.26^{*}$ \\
\hline Often & 0 & 0 & 3 & 100 & 3 & 2.8 & \\
\hline \multicolumn{8}{|c|}{ 03. Do you use reminders to take your medications at correct times? } \\
\hline Never & 42 & 45.2 & 51 & 54.8 & 93 & 85.4 & \\
\hline Rarely & 0 & 0 & 2 & 100 & 2 & 1.8 & \\
\hline Usually & 0 & 0 & 1 & 100 & 1 & 0.9 & $0.81 *$ \\
\hline Often & 1 & 50 & 1 & 50 & 2 & 1.8 & \\
\hline Always & 4 & 36,4 & 7 & 63,6 & 11 & 10.1 & \\
\hline \multicolumn{8}{|c|}{ 04. Did you doctor alter your anti-hypertensive drugs? } \\
\hline Never & 24 & 43.6 & 31 & 56.4 & 55 & 50.5 & \\
\hline Rarely & 18 & 51.4 & 17 & 48.6 & 35 & 32.1 & $0.20 *$ \\
\hline Often & 5 & 26.3 & 14 & 73.7 & 19 & 17.4 & \\
\hline \multicolumn{8}{|c|}{ 05. Number of antihypertensive drugs used: } \\
\hline 1 & 20 & 47.6 & 22 & 52.4 & 42 & 38.5 & $0.015^{*}$ \\
\hline 2 & 15 & 30 & 35 & 70 & 50 & 45.9 & \\
\hline$\geq 3$ & 12 & 70,6 & 5 & 29.4 & 17 & 15.6 & \\
\hline \multicolumn{8}{|c|}{ 06. Number of antihypertensive pills taken daily: } \\
\hline 1 to 3 & 32 & 42.7 & 43 & 57.3 & 75 & 68.8 & $0.71 *$ \\
\hline 4 to 6 & 9 & 39.1 & 14 & 60.9 & 23 & 21.1 & \\
\hline$\geq 7$ & 6 & 54.6 & 5 & 45.4 & 11 & 10.1 & \\
\hline
\end{tabular}

* Fisher's test

doctor-patient relationship in scientific studies, clinical education, and practice, by application of communication techniques that may enable a better relationship. Health professionals and service users must be partners. It is unfair that users must assume the burden of adhering, without receiving the necessary tools to play their roles under equal conditions, such as broad and adequate knowledge, social and emotional support, health system and medication access (Reiners, 2005).

One of the crucial factors to adherence is the patient's trust in their prescription and in the healthcare team or the physician (Leite, Vasconcelos, 2003). Svenssom et al. (2000) investigated the main reasons reported by the patients for adhering to anti-hypertensive medications, namely the trust in the doctor, fear of complications of hypertension and a desire to control blood pressure.
Nonadherent patients strive to minimize adverse effects and facilitate daily life, and frequently justify their nonadherence as an active decision. A better doctor-patient relationship has both a positive effect on users' satisfaction and quality of health service and a direct influence on these patients' health status (Caprara, Rodrigues, 2004).

Although it is believed that increasing complexity of medication regimen results in lower treatment adherence, in the present study, patients with higher adherence were taking 3 or more anti-hypertensive medications daily $(70.6 \%)$ and 7 or more anti-hypertensive pills daily (54.6\%) (Caprara, Rodrigues, 2004).

Patients' belief about the necessity of taking medications is a higher and better predictor of adherence than clinical and socio-demographic factors. Patients that do not consider taking medication important may reject 
therapeutic regimens including numerous medications. Shalasky and Levy (2002) estimated that approximately 14 to $20 \%$ of prescription were never presented at the pharmacies, and reported that the patient's belief that medication is unnecessary was the main cause of adherence failure.

Strelec (2000) found a high awareness level regarding disease and treatment, although this appeared not to influence blood pressure control. The inconsistency between the awareness of disease and treatment, and success in controlling blood pressure, indicates an essential difference between knowledge and adherence. While "knowledge" is regarded as a rational factor, adherence is a complex process involving important barriers of a logistic and practical order.

Conrad (1985) asserted that patients are not concerned with disobeying adherence to medical prescription or otherwise, but dealing with their life conditions in a convenient way that provides them with more self-control and freedom. Hence, adherence to prescribed therapy is a result of patient's assessment and acceptance of their health condition. Several factors that influenced non-compliance were identified by hypertensive patients, such as: fear of using anti-hypertensive medications and becoming dependent on them for the rest of their lives, the confidence that natural remedies are effective in controlling hypertension; the belief that the disease has been cured provided blood pressure was controlled, as well as low awareness of hypertension treatment, risk factors, characteristics and complications (Gascón et al., 2004).

The interview is a powerful tool to elucidate patients' concepts and behavior. In order to optimize hypertension treatment, it is important to establish a cooperative relationship in which all doubts and difficulties about therapy can be identified and solved (Svensson et al., 2000). According to Dowell and Hudson (1997), treatment acceptance is closely linked to acceptance of the illness itself and weakly related to any other factor.

Some studies have shown that when pharmacists are included as members of multiprofessional teams, an increase in the hypertension control rate ensues. Moreover, drug interactions, non-adherence as well as cost, can all be reduced (Carter, Elliott, 2000).

This study reiterates the importance of professional/patient interaction, trust in the doctor and health professionals' attitude toward users. It corroborates the need for greater emphasis on patient education regarding hypertension as well as organization of permanent education courses for training of health professionals, addressing the correct use of medications, knowledge sharing, modifying beliefs and attitudes toward treatment and helping patients understand their health conditions. The pharmacist has been a key element in improving hypertensive patients' adherence to treatment by providing direct pharmaceutical attention. The pharmacist is a professional who is in a position of constant contact with patients, enabling the provision of information about the prescribed medications, the disease and its complication while optimizing the medication therapy as a health maintenance practice.

\section{REFERENCES}

CAPRARA, A.; RODRIGUES, J. Asymmetric doctor-patient relationship: rethinking the therapeutic bond. Ciênc. Saúde Colet., v.9, n.1, p.139-146, 2004.

CARTER, B.L.; ELLIOTT, W.J. The role of pharmacists in the detection, management, and control of hypertension: a national call to action. Pharmacotherapy, v.20, n.2, p.119$122,2000$.

CONRAD, P. The meaning of medication: another look at compliance. Soc. Sci. Med., v.20, n.1, p.29-37, 1985.

DOWELL, J.; HUDSON, H. A qualitative study of medicationtaking behaviour in primary care. Fam. Pract., v.14, n.5, p.369-375, 1997.

EISEN, S.A.; MILLER, D.K.; WOODWARD, R.S.; SPITZNAGEL, E.; PRZYBECK, T.R. The effect of prescribed daily dose frequency on patient medication compliance. Arch. Intern. Med., v.150, n.9, p.1881-1884, 1990.

FLACK, J.M.; NOVIKOV, S.V.; FERRARIO, C.M. Benefits of adherence to anti-hypertensive drug therapy. Eur. Heart J., v.17, p.16-20, 1996.

GARCIA, R.A.C. Os fatores de aderência ao tratamento farmacológico de hiperlipidemias em pacientes atendidos pela Secretaria de Saúde de Ribeirão Preto. Ribeirão Preto, 2003. 104 p. [Dissertação de Mestrado. Faculdade de Medicina de Ribeirão Preto, Universidade de São Paulo].

GASCÓN, J.; SÁNCHEZ-ORTUÑO, M.; LIOR, B.; SKIDMORE, D.; SATURNO, P.J. Why hypertensive patients do not comply with the treatment. Fam. Pract., v.21, n.2, p.125-130, 2004.

KATZ, J.R. Back to basics: providing effective patient teaching. Am. J. Nurs., v.97, n.5, p.33-36, 1997. 
LEITE, S.; VASCONCELOS, M.P.C. Adesão à terapêutica medicamentosa: elementos para a discussão de conceitos e pressupostos adotados na literatura. Cien. Saúde Colet., v.8, n.3, p.775-782, 2003.

LEVY, P.S.; LEMESHOW, S. Sampling of populations: methods and applications. New York: John Wiley \& Sons, 1991. $420 \mathrm{p}$.

MILSTEIN-MOSCATI, I.; PERSANO, S.; CASTRO, L.L.C. Aspectos metodológicos e comportamentais da adesão à terapêutica. In: CASTRO, L.L.C. Fundamentos de Farmacoepidemiologia. São Paulo: AG Gráfica e Editora, 2000. p.171-179.

MORISKY, D.E.; GREEN, L.W.; LEVINE, D.M. Concurrent and predictive of a self-reported measure of medication adherence. Med. Care, v.24, n.1, p.67-74, 1986.

OSTENBERG, L.; BLASCHKE, T. Adherence to medication. N. Engl. J. Med., v.353, n.5, p.487-497, 2005.

REINERS, A.A.O. Interação profissional de saúde e usuário hipertenso: contribuição para a não-adesão ao regime terapêutico. Ribeirão Preto, 2005. 156 p. [Tese de Doutorado. Escola de Enfermagem de Ribeirão Preto, Universidade de São Paulo].

SCHROEDER, K.; FAHEY, T.; EBRAHIM, S. How can we improve adherence to blood pressure-lowering medication in Ambulatory Care? Arch. Intern. Med., v.164, n.7, p.722$732,2004$.

SEMENCIW, R.M.; MORRISON, H.I.; MAO, Y.; JOHANSEN, H.; DAVIES, J.W.; WIGLE, D.T. Major risk factors for cardiovascular disease mortality in adults: results from the Nutrition Canada Survey Cohort. Int. J. Epidemiol., v.17, n.2, p.317-324, 1988.
SHALANSKY, S.J.; LEVY, A.R. Effect of number of medications on cardiovascular therapy adherence. Ann. Pharmacother., v.36, n.10, p.1532-1539, 2002.

SILVESTRE-BUSTO, C.; RAMALLE, E.; ARNAEZ, R.; FLOR, A.; GARCIA, J.; RAMIL, H.; NOTIVOL, M. Estúdio multicéntrico sobre adhesión al tratamiento em población infantil en atención primaria. Aten. Primaria, v.27, n.8, p.554-558, 2001.

SOCIEDADE BRASILEIRA DE HIPERTENSÃO (SBH). SOCIEDADE BRASILEIRA DE CARDIOLOGIA (SBC). SOCIEDADE BRASILEIRA DE NEFROLOGIA (SBN). V Diretrizes brasileiras de hipertensão arterial. Rev. Bras. Hipertens., v.13, n.4, p.260-312, 2006.

STRELEC, M.A.A.M. A influência do conhecimento sobre a doença e atitude frente à tomada dos remédios no controle da hipertensão arterial. São Paulo, 2000. 139p. [Dissertação de Mestrado. Escola de Enfermagem. Universidade de São Paulo].

SVENSSON, S.; KJELLGREN, K.; AHLNER, J.; SALJO, R. Reasons for adherence with antihypertensive medication. Int. J. Cardiol., v.76, n.2, p.157-163, 2000.

WORLD HEALTH ORGANIZATION. Adherence to long term therapies: evidence for action. Geneva, 2003. 198 p.

Received for publication on $26^{\text {th }}$ May 2009. Accepted for publication on $01^{\text {st }}$ July 2010. 